\title{
Creatine and maltodextrine dietetic supplementation in eventing horses at training
}

\author{
Alexandre Soares Fagundes ${ }^{1}$, Fernando Queiroz Almeida ${ }^{2}$, Fernanda Nascimento de Godoi ${ }^{1}$, \\ Eduardo Xavier Ferreira Migon ${ }^{3}$, Tiago Marques dos Santos ${ }^{1}$, Paula Vieira Evans Hossell \\ Laranjeira $^{1}$
}

\footnotetext{
1 Universidade Federal Rural do Rio de Janeiro (UFRRJ), Seropédica, RJ, Brazil.

2 Instituto de Veterinária, Universidade Federal Rural do Rio de Janeiro (UFRRJ), Seropédica, RJ, Brazil, $23890-971$.

${ }^{3}$ Escola de Equitação do Exército, Deodoro, Rio de Janeiro, RJ, Brazil.
}

\begin{abstract}
This study was carried out to evaluate the creatine and maltodextrine dietetic supplementation of eventing horses. The experimental period consisted of 56 days, with 20 horses, which were randomly divided into four groups with different diets. Diets were: diet without supplement (Control); diet supplemented with creatine, $44.4 \mathrm{mg} / \mathrm{kg}$ body weight/day (20 g creatine/horse/day); diet supplemented with creatine, $88.8 \mathrm{mg} / \mathrm{kg}$ body weight/day (40 g creatine/horse/day); diet supplemented with maltodextrine, $222.2 \mathrm{mg} / \mathrm{kg}$ body weight/day (100 g/horse/day), during three days before each test. Every horse was submitted to three tests. Blood samples and heart rate were collected at rest, immediately after the tests and 10 and 20 minutes after the test. Supplementation with creatine $(44.4 \mathrm{mg} / \mathrm{kg}$ body weight/day) and maltodextrine reduced plasma concentration of lactate in horses during tests. Supplementation of creatine and maltodextrine did not alter serum concentration of aspartate aminotransferase, $\gamma$-glutamyltransferase, urea or creatinine, but training affected blood biochemical variables in eventing horses.
\end{abstract}

Key Words: equine, ergogenics, nutrition

\section{Introduction}

Ergogenic substances $($ ergon $=$ work and genico $=$ producer) are used in order to improve the performance of sport horses (Harris \& Harris, 1999). Such substances are provided orally, in a single or associated manner, following the manufacturer's recommended dosage. The results of their use are contradictory due to the enormous individual interspecific variation; the small number of animals that takes part in such experiments; limitations regarding the procedures; high cost of research using horses, amongst other reasons (Harris \& Harris, 2005).

Creatine is an amino acid (metilguanidine acetic acid) naturally present in diets and in the muscular tissue. Despite the existence of reasons for creatine dietetic supplementation on horses, there is lack of appropriate evidence of its effect on their athletic performance (Harris \& Harris, 1999). Ferraz et al. (2006) verified that longperiod creatine dietetic supplementation (90 days) increased the aerobic capacity of purebred Arabian horses in endurance training, whereas D'Angelis et al. $(2005 ; 2007)$ verified that creatine supplementation, for 90 days, did not alter the composition of gluteus medius or Longissimus dorsi muscle in horses.
Maltodextrine is used as an energetic source, promoting the increase of the glicemic curve, once the glucose storage as glycogen on the muscular tissue happens in a smoother manner (Ivers, 2002). Its use has been experimentally evaluated providing the increase of time to fatigue occurrence when one uses intravenous glucose infusion during a moderate to intense exercise, minimizing the muscular glycogen depletion and consolidating thus improvement on exercise performance (Cullineras et al., 2002).

In search of the proper nutrition and feeding, the application of such knowledge in the various equestrian sports has become increasingly interesting. Eventing stands out and can be defined as the Equestrian Triathlon when, during three days, horse and rider must show elegance and precision in the dressage competition, courage and physical conditioning at the cross-country competition and flexibility on the last day, in the obstacle course.

To define a training protocol, important variables must be taken into account, such as: horse age, training level, horse behavior, time until the arrival of the targeting competition, type of surface in which the training shall be performed and type of equestrian sport practiced (Boffi, 2006). According to Lindner \& Boffi (2007), the best way to 
evaluate the competitive capacity of an athlete is during competition. However, in some circumstances it is more worthwhile to determine the athletic capacity of horses through physical tests, employed to estimate the competitive potential, in order to compare the quality of different horses or that of a horse with itself, or to know the response to the training and thus the efficiency of the training program.

Heart rate is much used to evaluate the competitive capacity of horses, although there are few studies in which it was really possible to differentiate a horse competitive capacity using this parameter (Lindner \& Boffi, 2007). Lactate blood concentration or serum concentration have been frequently employed along with the other parameters, and provide additional information regarding the actual athlete's conditioning, as the variable that presents the best correlation with the animal's competitive performance (Lindner, 2000). Studies evaluating horses trained on high-speed treadmills or outdoors have demonstrated that training promotes a smaller blood lactate concentration when at the same exercise intensity (Evans, 2004).

Training has significant effect on the liver function indicators. Tyler-McGowan et al. (1999) observed in horses, after a long period of treadmill training, the increase of plasma concentrations of $\gamma$-glutamyltransferase and bilirubin and also reduction of plasma concentrations of alkaline phosphatase. Raises on the muscular enzymes during long-period evaluation training are probably related to individual pathologies or to the increase of training intensity (McGowan, 2008).

The objective of this study was to evaluate the dietetic supplementation with creatine or maltodextrine in eventing horses at training under field tests.

\section{Material and Methods}

This experiment was conducted at the $2^{\circ}$ Regimento de Cavalaria e Guarda do Exército Brasileiro, in Rio de Janeiro, Brazil. Laboratory analyses were performed at the Laboratório de Pesquisas em Saúde Equina from the Instituto de Veterinária and at Laboratório de Bromatologia Animal of the Instituto de Zootecnia of Universidade Federal Rural do Rio de Janeiro.

Twenty Brasileiro de Hipismo, Thoroughbreds and Selle Français horses of the Escola de Equitação do Exército at the discipline Eventing, with average weight of $450 \mathrm{~kg}$ and age ranging from six to eight years, of both sexes were used in the experiment. During the experimental period, all horses were homogeneous as for the time of training and were ridden exclusively by the same rider, summing up 20 sets of horserider, with 20 horses and 20 riders. The horse-rider set was formed at the beginning of the Equitation Instruction Course, remaining constant during training and receiving the same daily training instructions.

The experiment was completely randomized in a splitplot design, with four experimental diets (diets with and without supplements), five repetitions (animals), in three field tests during the training period. In the parcels, the diets were considered; in subparcels, the tests and the sampling time (measurement of heart rate and bloodsampling). The assay lasted 56 days, with the carrying out of three field tests, at the beginning, on the $28^{\text {th }}$ and $56^{\text {th }}$ days of the training period.

All horses were fed a diet composed of $6 \mathrm{~kg}$ of commercial concentrate (RH Rodeio ${ }^{\circledR}$ - Socil) supplied in fractions at 5 a.m., 1 p.m. and 11 p.m., and 3 kg of coast-cross hay (Cynodon dactylon (L) Pers) supplied at 7:30 a.m. and 7:30 p.m., always in an equal fraction following the Military Unit schedule and routine. Diet was provided at concentrate:forage proportion of 67:33, fed equivalent to $1.8 \%$ of body weight, in the dry matter, aiming to attend the daily requirements of digestible energy of horses in moderate physical activity according to the NRC (1989), of 22.4 Mcal. (Table 1).

The experiment was defined with experimental diets: diet without supplementation (control); diet with daily supplementation of creatine (Creatina ${ }^{\circledR}$ - Vetnil), at the dosage of $44.4 \mathrm{mg} / \mathrm{kg}$ body weight ( $20 \mathrm{~g}$ creatine/animal/day) during training period of 56 days; diet with daily supplementation of creatine, at the dosage of $88.8 \mathrm{mg} / \mathrm{kg}$ body weight (40g creatine/animal/day) during the 56-day training period; diet supplemented with maltodextrine (Maltodextril ${ }^{\circledR}$ - Vetnil), at the dosage of $111.1 \mathrm{mg} / \mathrm{kg}$ body weight, at every 12 hours (100 g maltodextrine/animal/day), at a period of three days before each test, according to manufacturer's indications.

Creatine was added to the ration, at the 1 p.m. meal, during the 56 days of the training period. Creatine administration along with the ration was employed in order to make it easier and reassure its full intake. Maltodextrine was provided orally, at the daily dosage of $100 \mathrm{~g}$ per animal/day, divided in two portions of $50 \mathrm{~g}$ and added to the ration, at $5 \mathrm{a} . \mathrm{m}$. and

Table 1 - Composition of concentrate and coast-cross hay (\%DM)

\begin{tabular}{|c|c|c|}
\hline Nutrient $^{1}$ & Concentrate & Coast-cross hay \\
\hline Dry matter & 88.7 & 87.4 \\
\hline Organic matter & 82.8 & 93.2 \\
\hline Crude protein & 11.2 & 3.5 \\
\hline Neutral detergent fiber & 44.8 & 79.9 \\
\hline Acid detergent fiber & 16.4 & 35.7 \\
\hline Digestible energy (Mcal/kg DM) ${ }^{2}$ & 3.1 & 2.2 \\
\hline
\end{tabular}

${ }^{1}$ Analysis were done according to Silva \& Queiroz (2002).

2 Digestible energy (DE) was estimated through the equation $\mathrm{DE}=3.7868-$ 0.044 (\%FDA) (Almeida et al., 1999). 
1 p.m., totaling five administrations before each test, considering that, on the test day, maltodextrine was added in only one meal, at 5 a.m., before the test.

During the experimental period daily intake was monitored and, every 15 days, there was an evaluation of body weight and body score, in accordance with Henneke et al. (1983) methodology. Horses were submitted to specific training at the eventing discipline of the Equitação da Escola de Equitação do Exército. The daily training consisted of one hour in physical activity, including both physical and technical preparation of the animals for participation in nationwide events, in the “young horses” category. On average, training consisted of 17 minutes in walk pace, 30 minutes trotting and 11 minutes of cantering, in several speeds, and the remaining time was spent with the practice of jumping exercises.

The physical effort test was performed aiming to increase cardiac and respiratory gain by the method called interval training, composed of stages with several types of gaits along with periods of rest (Evans, 2000). Tests were performed on a plain, oval circuit of $925 \mathrm{~m}$, with grass floor, under the following protocol: a warming up period of 17 minutes of walking at the speed of $1.7 \mathrm{~m} / \mathrm{s}$ and trot, at $4.0 \mathrm{~m} / \mathrm{s}$ speed, followed by 3 minutes of cantering at the speed of $7.5 \mathrm{~m} / \mathrm{s}$ ( $450 \mathrm{~m} / \mathrm{min}) ; 3$ minutes walking; 3 minutes of cantering: 90 seconds at $7.5 \mathrm{~m} / \mathrm{s}(450 \mathrm{~m} / \mathrm{min})$ and the final 90 seconds in free speed, without the use of whips or spurs. Speeds were determined trough the monitoring of time and distance, known and pre-determined. During the test there was the formation of five distinct groups of 4 sets, each set formed by horse and rider, in a total of 20 sets. Horses were fed the concentrate 5 hours before the beginning of test (Almeida et al., 2003).

Prior to the experimental period, with the horses at rest in the stalls, blood-sampling was taken with vacuum tubes with anti-clotting (EDTA). Hematocrit (PVC) analysis was done through the microhematocrit method. White blood cell count was evaluated through the counting of cells in the Newbawer chamber. Fibrinogen concentration was obtained by the refratometry technique (Coles, 1984).

During the research, the first heart rate evaluation and the blood-sampling occurred before the each test, with the horses at rest inside the stalls. Blood-sampling was taken with vacuum tubes with sodium fluorite, in order to do the analysis of glucose and lactate. The remaining analysis and sampling were performed immediately after the end of the test and at 10 and 20 minutes after the end, with the horses kept at walking pace. On the test day, at rest and 120 minutes after the finishing of the tests, with the horses in their stalls, blood samples for blood biochemical analysis were collected in vacuum tubes without anti-clotting, to determine serum levels of aminotranferase aspartate, $\boldsymbol{\gamma}$-glutamyltransferase, urea and creatinine.

After blood-sampling, samples were centrifuged at 7,000 rpm for 10 minutes, aiming at the separation of blood plasma (in the samples collected in tubes with the sodium fluorite) for the glucose and lactate analysis, or separation of the blood serum (in the samples collected in tubes without anti-clotting), for the analysis of aminotranferase aspartate, $\gamma$-glutamyltransferase, urea and creatinine. Portions of $1 \mathrm{~mL}$ were taken with the use of automatic pipette and stored at $-18^{\circ} \mathrm{C}$, in $1.5 \mathrm{~mL}$ polypropylene tubes until the moment of analysis. Plasma lactate and glucose concentrations were analyzed through a commercial kit (Sigma Diagnostics ${ }^{\circledR}$ ) with the use of a spectrophotometer. Serum concentrations of aminotranferase aspartate and $\gamma$-glutamyltransferase, urea and creatinine were evaluated using the spectrophotometer, also through commercial kits $\left(\right.$ Bioclin $^{\circledR}$ ).

The values of physiological, hematological and biochemical variables were submitted to variance analysis in a split-plot design and compared by the Student NewmanKeuls test, with 5\% probability, with the Statistics and Genetics Analysis Software-SAEG (UFV, 2000).

\section{Results and Discussion}

Digestible energy daily intake was higher than cited by the NRC (1989) for horses in moderate physical activity, 22.3 Mcal, but similar to requirements cited by NRC (2007), $24 \mathrm{Mcal}$, for horses in intense physical activity. Daily intake of crude protein was of $777 \mathrm{~g}$, inferior to requirements cited by NRC (1989) for horses in moderate physical activity, $894 \mathrm{~g}$, but in accordance with the NRC (2007) for horses in intense physical activity, of 776 g daily.

The intake of creatine or matodextrine supplemented diets at the present study did not influence heart rate of horses in the tests, with values equivalent to submaximum effort, where one must consider that the measurement of heart rate happened about one minute after the end of the last canter (Table 2). Godoi et al. (2010), evaluating eventing horses observed similar values of heart rate at rest, ranging from 33 to 40 beats/min. However, immediately after the end of the test, following the same protocol used in this study, horses presented more elevated heart rate values, ranging from 102 to 133 beats/min. Such difference might have occurred due to the horses' training level and environmental temperature on the days when tests took place.

The training effect was observed $(\mathrm{P}<0.05)$ by the reduction of $19 \%$ and $25 \%$ of heart rate immediately after the 
tests on the $28^{\text {th }}$ and $56^{\text {th }}$ training days, respectively. In the same way, at 10 minutes after the test, the horses' heart rate values on the $2^{\text {nd }}$ and $3^{\text {rd }}$ test, were lower than those on the $1^{\text {st }}$ tests, pointing to an improvement on the horses' conditioning and a fast decrease of heart rate, of about $63 \%$ of the heart rate observed immediately after the test. At 20 minutes after the test, there was no difference ( $\mathrm{P}>0.05$ ) in horses' average heart rate, with values ranging from 50 to $60 \%$ of the heart rate values observed immediately after the tests.

There was no effect of the creatine or maltodextrine supplementation on glucose plasma concentration in the horses $(\mathrm{P}>0.05)$ (Table 3$)$. However, it was possible to observe training effect of the horses, with difference between the tests $(\mathrm{P}>0.05)$.

Regarding the first test, the glucose plasma concentration was lower immediately after the test, of $61.30 \mathrm{mg} / \mathrm{dL}$, recovering the normal levels 20 minutes after the end of the test. Considering the second test, there was no difference ( $P>0.05$ ) before and after the test. At the third test, glucose plasma concentration decreased up to the 10 minutes after the end of the test, of $94.9 \mathrm{mg} / \mathrm{dL}$, reaching normal levels after 20 minutes, of $99.7 \mathrm{mg} / \mathrm{dL}$. Plasma glucose concentration pre and post test increased during experimental period, which might have occurred due to the bigger glucose availability for the exercise. According to Pösö et al. (2004), the changes in the glucose concentration levels depend on the type of the exercise that is performed. Glucose plasma concentration tends to reduce during prolonged exercises whereas during short exercises, increase and decrease have been observed.

According to Andrews et al. (1995) glucose plasma concentrations are frequently used in order to evaluate the energetic metabolism. The plasma concentration of these metabolites can be affected by several factors, being the result of a balance between the glucose offer and demand on the blood circulation, an important source of energy for the muscular activity, as it can be observed at the $1^{\text {st }}$ and $3^{\text {rd }}$ physical effort tests, notably at the $3^{\text {rd }}$ one. Nevertheless, all results are within the reference values quoted by Hodgson \& Rose (1994).

The impact of the availability of carbohydrates and its oxidation during the performance exercise is demonstrated in horses in two situations: by increase of fatigue time of horses that have received intravenous glucose during the medium or high intensity exercise and by depletion of muscular glycogen before the exercise, demonstrating thus subsequent loss in performance (Lacombe et al., 1999).

Evaluating glycogen muscular depletion in horses and their capacity of replenishing them, Lacombe et al. (2001) made intravenous infusions with a $0.9 \%$ physiological solution and glucose at the concentration of $6 \mathrm{~g} / \mathrm{kg}$ body weight, and submitted animals to high intensity exercise at $120 \%$ of $\max \mathrm{VO}_{2}$. These authors concluded that after exhaustion of muscular glycogen, there was higher glycemic index, smaller fatigue during the competition,

Table 2 - Average values and standard deviation of heart rate in eventing horses in three field tests

\begin{tabular}{lrcc}
\hline Time & & Test & \\
\cline { 2 - 3 } & $1^{\text {st }}$ & $2^{\text {nd }}$ & $3^{\text {rd }}$ \\
\hline & & Heart rate (beats/min) & $36.6 \pm 5.3 \mathrm{Ac}$ \\
At rest & $41.6 \pm 9.09 \mathrm{Ad}$ & $39.1 \pm 6.86 \mathrm{Ad}$ & $88.2 \pm 18.5 \mathrm{Ba}$ \\
Immediately after the test & $116.7 \pm 33.5 \mathrm{Aa}$ & $59.7 \pm 11.3 \mathrm{Bb}$ & $58.6 \pm 10.1 \mathrm{Bb}$ \\
10 minutes after the test & $70.6 \pm 29.3 \mathrm{Ab}$ & $53.5 \pm 11.7 \mathrm{Ac}$ & $54.5 \pm 7.8 \mathrm{Ab}$ \\
20 minutes after the test & $56.5 \pm 18.6 \mathrm{Ac}$ & \\
\hline
\end{tabular}

Means in the rows, followed by the same capital letters do not differ $(\mathrm{P}>0.05)$ by SNK test.

Means in the columns, followed by the same lowercase letters do not differ $(\mathrm{P}>0.05)$ by SNK test. Coefficient of variance $=8.6 \%$.

Table 3 - Average values and standard deviation of plasma glucose concentration in eventing horses in three field tests

\begin{tabular}{lccc}
\hline Time & \multicolumn{2}{c}{ Test } \\
\cline { 3 - 4 } & $1^{\text {st }}$ & $2^{\text {nd }}$ & $3^{\text {rd }}$ \\
\hline At rest & & Plasma glucose $(\mathrm{mg} / \mathrm{dL})$ & $92.2 \pm 6.0 \mathrm{Ba}$ \\
Immediately after the test & $83.4 \pm 7.7 \mathrm{Ca}$ & $86.9 \pm 12.5 \mathrm{Aa}$ & $105.8 \pm 20.0 \mathrm{Aa}$ \\
10 minutes after the test & $61.3 \pm 13.9 \mathrm{Bb}$ & $81.7 \pm 8.3 \mathrm{Ba}$ & $87.2 \pm 15.4 \mathrm{Ac}$ \\
20 minutes after the test & $79.2 \pm 15.8 \mathrm{Ba}$ & $89.2 \pm 6.2 \mathrm{Ba}$ & $94.9 \pm 8.8 \mathrm{Ab}$ \\
Normal variation $(\mathrm{mg} / \mathrm{dL})^{1}$ & $85.0 \pm 11.8 \mathrm{Ba}$ & $70-140$ & $99.7 \pm 7.8 \mathrm{Aa}$ \\
\end{tabular}

Means in the rows, followed by the same capital letters do not differ $(\mathrm{P}>0.05)$ by SNK test.

Means in the columns, followed by the same lowercase letters do not differ $(\mathrm{P}>0.05)$ by SNK test.

Coefficient of variance $=6.2 \%$.

${ }^{1}$ Hodgson \& Rose (1994). 
smaller oxygen deficit store and smaller lactate plasma concentration.

In horses fed on concentrate, an increase at glucose and insulin plasma concentrations was observed one hour after ingestion. However, when horses had a diet supplemented with D-fructose, glucose or 50\% fructose/ $50 \%$ glucose, no significant effect on the glucose pick concentration was observed, not even at the time of the occurrence of glucose pick (Bullimore et al., 2000). However, Vervuert et al. (2004) observed that glucose plasma levels were significantly higher after glucose supplementation provided before or during the exercise and that fructose presented no advantage at all in comparison with the supply of glucose and soluble carbohydrates to endurance horses.

There was effect of creatine dietetic supplementation at the daily dosage of $20 \mathrm{~g}$ and maltodextrine on lactate plasma levels of horses in the tests $(\mathrm{P}<0.05)$ (Table 4$)$. Horses fed on maltodextrine supplemented diets showed better results, once their lactate blood concentration was significantly lower at all the times after the test. Lactate plasma concentrations immediately after the test of horses fed control diet or the diet supplemented with $40 \mathrm{~g}$ of creatine had no significant difference and presented higher values, of 6.11 and $5.83 \mathrm{mmol} \mathrm{dL}^{-1}$, respectively.

Studies on the effects of long-term dietary creatine supplementation in horses are scarce. Greenhaff (1997) observed that human athletes eating creatine for a long time may have benefits in delaying fatigue during training at intensity higher than usual. Van Loon et al. (2004) observed in humans that creatine dietetic supplementation at high concentrations increases the muscular glycogen concentration, but such effect was not observed on the long-term supplementation.

Ferraz et al. (2006) verified an increase in endurance performance of purebred Arabian horses with creatine dietetic supplementation, at the daily dosage of approximately $192 \mathrm{mg} / \mathrm{kg}$ of body weight, during 90 days, with the decrease of blood lactate accumulation. In the present research, creatine was used in daily dosages of 44.4 and $88.8 \mathrm{mg} / \mathrm{kg}$ body weight, during 56 days, and a significant reduction on the lactate plasma concentration was observed after the tests in eventing horses fed creatine in daily dosage of $44.4 \mathrm{mg} / \mathrm{kg}$. These results emphasize the necessity of more studies about creatine dosage to dietetic supplementation as well as the appropriate supplementation to other equestrian sports.

Horses feed on control diet (without supplementation), had lactate plasma concentration profile within the expected, with higher values immediately after the end of the test, of $6.11 \mathrm{mmol} \mathrm{dL}^{-1}$ decreasing until the value of $2.39 \mathrm{mmol} \mathrm{dL}^{-1}$ after a 20 -minute recovery. Godoi et al. (2010) evaluating horses under the same exercise protocol as in this study, also observed a similar lactate concentration profile immediately after the end of the test, with values ranging from 6.2 to $4.1 \mathrm{mmol} \mathrm{dL}^{-1}$. It is possible to have a plasma concentration of lactate as an indicator of excessive training or even that of less trained or conditioned individuals, once the maintenance of its high levels can indicate a possible exhaustion in both situations.

Creatine dietetic supplementations, at the dosages of 20 and $40 \mathrm{~g} /$ animal/day, and maltodextrine at the dosage of $100 \mathrm{~g} / \mathrm{animal} /$ day, did not influence $(\mathrm{P}>0.05)$ aminotranferase aspartate, $\gamma$-glutamyltransferase, urea or creatinine serum values in the horses (Table 5), but the effect of the time of training was observed.

Serum concentrations of aminotranferase aspartate increased $(\mathrm{P}<0.05)$ on the $56^{\text {th }}$ training day, with mean values of $286.1 \mathrm{U} \mathrm{L}^{-1}$, which might have occurred because the horses were at the final training phase, with a higher requirement for muscular work. However, all values were within the reference limits (Hodgson \& Rose, 1994), certifying thus the absence of muscular damages in such animals.

Ribeiro et al. (2004) observed that the serum levels of aminotranferase aspartate in horses and hinnies in a $76 \mathrm{~km}$

Table 4 - Average values and standard deviation of plasma lactate concentration in eventing horses fed creatine and maltodextrine supplemented diets

\begin{tabular}{|c|c|c|c|c|}
\hline \multirow[t]{2}{*}{ Time } & \multicolumn{4}{|c|}{ Experimental diets } \\
\hline & Control & Creatine 20g & Creatine $40 \mathrm{~g}$ & Maltodextrine \\
\hline & \multicolumn{4}{|c|}{ Plasma lactate $\left(\mathrm{mmol} \mathrm{dL}^{-1}\right)$} \\
\hline Immediately after the test & $6.11 \pm 2.08 \mathrm{Aa}$ & $4.17 \pm 2.12 \mathrm{Ba}$ & $5.83 \pm 3.03 \mathrm{Aa}$ & $3.05 \pm 1.88 \mathrm{Ca}$ \\
\hline 10 minutes after the test & $3.83 \pm 1.93 \mathrm{Ab}$ & $2.83 \pm 2.65 \mathrm{Bb}$ & $4.78 \pm 3.15 \mathrm{Ab}$ & $1.63 \pm 1.08 \mathrm{Cb}$ \\
\hline 20 minutes after the test & $2.39 \pm 1.50 \mathrm{Ac}$ & $1.69 \pm 1.68 \mathrm{Bc}$ & $3.36 \pm 2.77 \mathrm{Ac}$ & $1.21 \pm 0.59 \mathrm{Cb}$ \\
\hline
\end{tabular}

Means in the rows, followed by the same capital letters do not differ $(\mathrm{P}>0.05)$ by SNK test.

Means in the columns, followed by the same lowercase letters do not differ $(\mathrm{P}>0.05)$ by SNK test.

Coefficient of variance $=19.1 \%$.

${ }^{1}$ Hodgson \& Rose (1994). 
endurance test were not altered during the physical effort. According to Boffi (2006), the AST concentrations presented a maximum level of about 12 to 24 hours after the muscular damage was done, and there would be a need to increase the normal values of this enzyme by 5 to 100 times so that the muscular damage could be certified.

The effect of training on the $\gamma$-glutamyltransferase serum concentration $(\mathrm{P}<0.05)$ was also observed in all three tests, with a higher value at the beginning of the experimental period, of $18.3 \mathrm{U} \mathrm{L}^{-1}$. However, such value was within the limits of normality (Hodgson \& Rose, 1994). In such manner, it can be inferred that horses that have creatine or maltodextrine supplemented diets intake during 56 days did not present liver tissue alterations.

There was effect of the training on the urea and creatinine serum concentrations, with reduction of such values only on the $56^{\text {th }}$ training day $(\mathrm{P}<0.05)$ with values of 33.9 and $1.2 \mathrm{mg} \mathrm{dL}^{-1}$, respectively. Some authors (Rose et al., 1982; Snow et al., 1982; Fernandes et al., 2000) have shown the elevation of urea serum levels in horses in endurance competitions, and have attributed the results to breeding differences, as well as to the type and duration of the exercise and the level of the animals' conditioning.
At the first test, before the creatine or maltodextrine dietetic supplementation, no difference in the horses' hematocrit values or white blood cell count was found, but fibrinogen values were different between the horses' groups (Table 6). At the second test, after 28 days of training, horses with maltodextrine supplemented diet presented lower values on the hematocrit. Nevertheless, on the third test, 56 days after training, the lower hematocrit value was observed in horses fed on the control diet, showing that the intake of the supplements did not change horses' hematocrit value, which might have been due to the effect of training, amongst other reasons. Average hematocrit values, in disregard of the supplemented diets intake and training period, are below those cited by Hodgson \& Rose (1994), ranging from 38 to $42 \%$.

Hematocrit alterations in horses might have happened due to the breed factor and to the sportive activity, once the quoted literature (Hodgson \& Rose, 1994) uses as reference Thoroughbred horses at racing. In studies conducted with horses of Brazilian breeds, hematocrit values similar to the ones presented in this research were observed. Lacerda et al. (2006), evaluating Brasileiro de Hipismo horses observed hematocrit values of 33.5\%; Mattos et al. (2006),

Table 5 - Serum concentrations of aminotransferase aspartate (AST), $\boldsymbol{\gamma}$-glutamyltransferase (GGT), urea and creatinine in eventing horses in three field tests

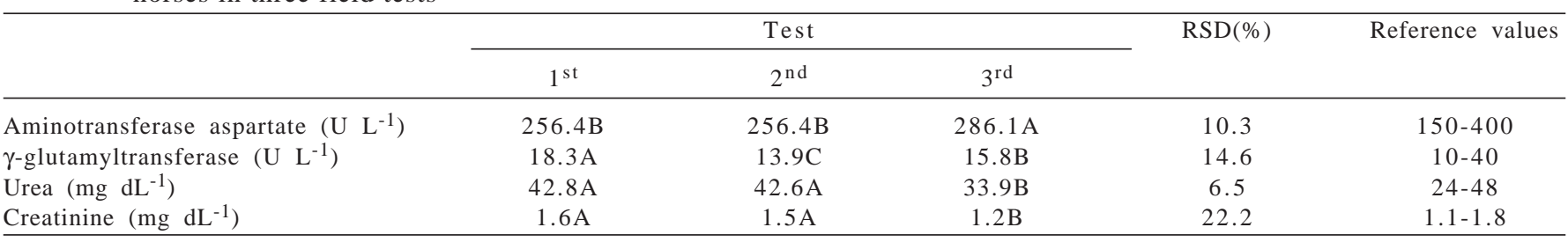

Means in the rows, followed by the same capital letters do not differ $(\mathrm{P}>0.05)$ by SNK test.

RSD - Relative standard deviation.

${ }^{1}$ Hodgson \& Rose (1994).

Table 6 - Average values of hematocrit, total leukocyte and fibrinogen in eventing horses in three tests

\begin{tabular}{|c|c|c|c|c|}
\hline \multirow[t]{2}{*}{ Item } & \multicolumn{4}{|c|}{ Experimental diets } \\
\hline & Control & Creatine $20 \mathrm{~g}$ & Creatine $40 \mathrm{~g}$ & Maltodextrine \\
\hline & \multicolumn{4}{|c|}{$1^{\text {st }}$ test } \\
\hline White blood cell $\left(/ \mathrm{mm}^{6}\right)$ & $8.5 \mathrm{Aa}$ & $9.0 \mathrm{Aa}$ & 8.4Aa & 8.6Aa \\
\hline \multirow[t]{2}{*}{ Fibrinogen (mg dL $\mathrm{d}^{-1}$ ) } & $275 \mathrm{ABa}$ & $400 \mathrm{ABa}$ & $400 \mathrm{Aa}$ & $220 \mathrm{Ba}$ \\
\hline & \multicolumn{4}{|c|}{$2^{\text {nd }}$ test } \\
\hline \multirow[t]{2}{*}{ Fibrinogen $\left(\mathrm{mg} \mathrm{dL}^{-1}\right)$} & $280 \mathrm{ABa}$ & $240 \mathrm{Ab}$ & $280 \mathrm{Ab}$ & $360 \mathrm{ABa}$ \\
\hline & \multicolumn{4}{|c|}{$3^{\text {rd }}$ test } \\
\hline Hematocrit (\%) & 31.0BCa & $33.0 \mathrm{ABa}$ & $31.0 \mathrm{ABa}$ & $30.6 \mathrm{ABa}$ \\
\hline White blood cell $\left(/ \mathrm{mm}^{6}\right)$ & $9.5 \mathrm{Aa}$ & $9.7 \mathrm{Aa}$ & $6.8 \mathrm{Ba}$ & $9.9 \mathrm{Aa}$ \\
\hline Fibrinogen (mg dL $\left.{ }^{-1}\right)$ & $180 \mathrm{ABa}$ & $220 \mathrm{Ab}$ & $200 \mathrm{Ab}$ & $280 \mathrm{ABa}$ \\
\hline
\end{tabular}

Means in the rows, followed by the same capital letters do not differ $(\mathrm{P}>0.05)$ by SNK test.

Means in the columns, followed by the same lowercase letters do not differ $(\mathrm{P}>0.05)$ by SNK test.

${ }^{1}$ Reference values: hematocrit: 38 a 42\%; White blood cell count 6.0 - 11.0 /mm ${ }^{6}$; Fibrinogen: <400 mg dL ${ }^{-1}$ (Hodgson \& Rose, 1994 ). 
evaluating horses under trotting observed PVCs of 32.1\%; and Ribeiro et al. (2008), evaluating Pantaneiro horses at sporting activities, observed hematocrit values of $32 \%$. Finally, Godoi et al. (2009), evaluating eventing horses, similar to those of this study, observed mean PVC values of $32.8 \%$.

White blood cell, which is used as an indicator of infectious processes only presented decrease after 56 days of the experimental period in horses fed the supplemented diets with $40 \mathrm{~g}$ of creatine (when compared with those fed the supplemented diets with $20 \mathrm{~g}$ of creatine). However, this alteration was not relevant enough to display any clinical conditions. All means were within the normality according to the reference values proposed by Hodgson \& Rose (1994).

Horses fed diets supplemented with 20 or $40 \mathrm{~g}$ of creatine presented a decrease $(\mathrm{P}<0.05)$ in fibrinogen over the training. However, horses' values in the beginning of the assay were above the other treatments, thus the differences, after the $28^{\text {th }}$ and $56^{\text {th }}$ days of training, which might just be a reestablishment of normal values. All values observed are within the normality cited by Hodgson \& Rose (1994), suggesting that the horses were healthy, as fibrinogen is an indicator of inflammatory processes.

\section{Conclusions}

Creatine and maltodextrine supplementation enables the decrease of lactate plasma levels during exercise, minimizing risks of metabolic disorders. The creatine dietetic supplementation at the dosage of 20 and $40 \mathrm{~g} / \mathrm{animal} / \mathrm{day}$, and maltodextrine, at the dosage of $100 \mathrm{~g} / \mathrm{animal} / \mathrm{day}$ do not alter the serum levels of aminotransferase aspartate, $\gamma$-glutamyltransferase, urea or creatinine. However, training does affect the serum biochemistry of eventing horses.

\section{Acknowledgments}

To the Escola de Equitação do Exército and Vetnil ${ }^{\circledR}$ for their support and encouragement of research with horses.

\section{References}

ALMeIDA, F.Q.; PATITUCCI, L.T.; MigON, E.X.F. et al. Plasma lactate evaluation in three days events horses. In: WORLD EQUINE VETERINARY ASSOCIATION CONGRESS, 8., 2003, Buenos Aires. Proceedings... Buenos Aires: WEVA, 2003.

ALMEIDA, M.I.V.; FERREIRA, W.M.; ALMEIDA, F.Q. et al. Composição química e predição do valor nutritivo de dietas para equinos. Revista Brasileira de Zootecnia, v.28, n.6, p.1268-1278, 1999.

ANDREWS, F.M.; GEISER, D.R.; WHITE, S.L. et al. Haematological and biochemical changes in horses competing in a 3 star horse trial and 3-day-event. Equine Veterinary Journal, Suppl. n.20, p.57-63, 1995.

BOFFI, F.M. Principios de entrenamiento. In: BOFFI F. M. (Ed.) Fisiologia del ejercicio em equinos. Buenos Aires: InterMédica, 2006.p.223-241.

BULLIMORE, S.R.; PAGAN, J.D.; HARRIS, P.A. et al. Carbohydrate supplementation of horses during endurance exercise: comparison of fructose and glucose. Journal of Nutrition, v.130, n.7, p.1760-1765, 2000.

COLES, E.H. Patologia clínica veterinária. 3.ed. São Paulo: MANOLE, 1984. 566p.

CULLINERAS, E.J.; HINCHCLIFF, K.W.; SAMS, R.A. et al. Glycemic index of a meal fed before exercise alters substrate use and glucose flux in exercising horses. Journal of Applied Physiology, v.92, p.117-128, 2002.

D’ANGELIS, F.H.F.; FERRAZ, G.C.; BOLELI, I.C. et al. Aerobic training, but not creatine supplementation, alters the gluteus medius muscle. Journal of Animal Science, v.83, p.579-585, 2005.

D’ANGELIS, F.H.F.; MOTA, D.S.; FREITAS, E.V.V. et al. Aerobic training, but not creatine, modifes Longissimus dorsi muscle composition. Journal of Equine Veterinary Science, v.27, n.3, p.118-122, 2007.

EVANS, D.L. Exercise testing in the field. In: HINCHCLIFF, K.W.; KANEPS, A.J.; GEOR, R.J. Equine sports medicine and surgery. Philadelphia: Saunders, 2004. p.19-31.

EVANS, D.L. Training and fitness in athletic horses. Sydney: RIRDC, 2000. 70p.

FERNANDES, W.R.; LARSSON, M.H.M.A. Alterações nas concentrações séricas de glicose, sódio, potássio, uréia e creatinina em equinos submetidos a provas de enduro de $30 \mathrm{Km}$ com velocidade controlada. Ciência Rural, v.30, n.3, p.393-398, 2000.

FERRAZ, G.C.; TEIXEIRA-NETO, A.R.; D‘ANGELIS, F.H.F. et al. Long-term creatine supplementation improves the aerobic capacity of horses. Ciência Rural, v.36, n.2, p.514-519, 2006.

GODOI, F.N.; ALMEIDA, F.Q.; GUARIENTI, G.A. et al. Perfil hematológico e características das fezes de equinos consumindo dietas hiperlipidêmicas. Ciência Rural, v.39, n.9, p.2571-2677, 2009.

GODOI, F.N.; ALMEIDA, F.Q.; MIGON, E.X.F. et al. Performance of eventing horses fed high fat diet. Revista Brasileira de Zootecnia, v.39, n.3, p.335-343, 2010.

GREENHAFF, P.L. The nutritional biochemistry of creatine. Nutritional Biochemistry, v.8, p.610-618, 1997.

HARRIS, P.A.; HARRIS, R.C. Ergogenic potential of nutritional strategies and substances in the horse. Livestock Production Science, v.92, p.47-165, 2005.

HARRIS, P.A.; HARRIS, R.C. Nutritional ergogenic aids in the horse- use and abuses. In: RECENT ADVANCES IN EQUINE NUTRITION, 1999, Kentucky. Proceedings... Kentucky: Kentucky Equine Research, 1999. p.83-104.

HENNEKE, D.R.; POTTER, G.D.; KREIDER, J.L. et al. Relationship between condition score, physical measurements and body fat percentage in mares. Equine Veterinary Journal, v.15, n.4, p.897-903, 1983.

HODGSON, D.R.; ROSE, R.J. The Athletic horse: principles and practice of equine sports medicine. Philadelphia: W.B. Saunders Co., 1994. 497p.

IVERS, T. Carbohydrates in Performance Horses. In: EUROPEAN EQUINE NUTRITION AND HEALTH CONGRESS, 1., 2002, Netherlands. Proceedings... Netherlands, 2002. p.1-11.

LACERDA, L.; CAMPOS, R.; SPERB, M. et al. Hematologic and biochemical parameters in three high performance horse breeds from Southern Brazil. Archives of Veterinary Science, v.11, n.2, p.40-44, 2006

LACOMBE, V.; HINCHCLIFF, K.W.; GEOR, R.J. et al. Exercise that induced substantial muscle glycogen depletion impairs subsequent anaerobic capacity. Equine Veterinary Journal, v.30, p.293-297, 1999. 
LACOMBE, V.A.; KENNETH, W.H.; RAY, J.G. et al. Muscle glycogen depletion and subsequent replenishment affect anaerobic capacity of horses. Journal of Applied Physiology, v.91, p.1782-1790, 2001.

LINDNER, A.E.; BOFFI, F.M. Pruebas de ejercicio. In: BOFFI, F.M. (Ed.) Fisiologia del ejercicio en equinos. Buenos Aires: Inter-Médica, 2007. p.243-254.

LINDNER, A. Use of blood biochemistry for positive performance diagnosis of sports horses in practice. Revue du Médecine Véterinaire, v.151, n.7, p.611-618, 2000.

MATTOS, F.; ARAÚJO, K.V.; LEITE, G.G. et al. Uso de óleo na dieta de equinos submetidos ao exercício. Revista Brasileira de Zootecnia, v.35, n.4, p.1373-1380, 2006.

McGOWAN, C. Clinical pathology in the racing horse: The role of clinical pathology in assesing fitness and performance in the racehorse. Veterinary Clinics of North America: Equine Practice, v.24, p.405-421, 2008.

NATIONAL RESEARCH COUNCIL - NRC. Nutrient requirements of horses. 5.ed. Washington, D.C.: 1989. 100p.

NATIONAL RESEARCH COUNCIL - NRC. Nutrient requirements of horses. 6.ed.rev. Washington, D.C.: National Academies Press, 2007. 341p.

PÖSÖ, A.R.; HYYPPÄ, S.; GEOR, R.J. Metabolic responses to exercise and training. In: HINCHCLIFF, K.W.; KANEPS, A.J.; GEOR, R.J. (Eds.) Equine sports medicine and surgery. Philadelphia: Saunders, 2004. p.771-792.

RIBEIRO, C.R.; FAGLIARI; J.J.; GALERA, P.D. et al. Hematological profile of healthy Pantaneiro horses. Arquivo Brasileiro de Medicina Veterinária e Zootecnia, v.60, n.2, p.492-495, 2008.
RIBEIRO, C.R.; MARTINS, E.A.N.; RIBAS, J.A.S. et al. Avaliação de constituintes séricos em equinos e muares submetidos à prova de resistência de $76 \mathrm{Km}$, no Pantanal do Mato Grosso, Brasil. Ciência Rural, v.34, n.4, p.1081-1086, 2004.

ROSE, R.J.; ALLEN, J.R.; HODGSON, D.R. Hematological, and plasma biochemical parameters in endurance horses during training. Equine Veterinary Journal, v.14, n.2, p.144-148, 1982.

SILVA, D.J.; QUEIROZ, A.C. Análise de alimentos: métodos químicos e biológicos. 3.ed.Viçosa, MG: UFV, Imprensa Universitária, 2002. 182p.

SNOW, D.H.; KERR, M.G.; NIMMO, M.A. Alterations in blood, sweat, urine and muscle composition during prolonged exercise in the horse. Veterinary Record, v.110, n.16, p.377-384, 1982.

TYLER-McGOWAN, C.M.; GOLLAND, L.C.; EVANS, D.L. Haematologic and biochemical responses to training and overtraining. Equine Veterinary Journal, v.30, p.621-625, 1999.

UNIVERSIDADE FEDERAL DE VIÇOSA - UFV. Sistema de análises estatísticas e genéticas - SAEG. Versão 8.0 . Viçosa, MG, 2000. 142p.

VAN LOON, L.J.C.; MURPHY, R.; OOSTERLAAR, A.M. et al. Creatine supplementation increases glycogen storage but not GLUT-4 expression in human skeletal muscle. Clinical Science, v.106, p.99-106, 2004.

VERVUERT, I.; COENEN, M.; BOTHE, C. Effects of corn processing on the glycaemic and insulinaemic responses in horses. Journal of Animal Physiology and Animal Nutrition, v.88, p.348-355, 2004 